\title{
Integrative Analysis of IncRNA-miRNA-mRNA Regulatory Network Reveals Candidate IncRNAs Responsible for Meat Quality in Goats
}

\section{Changsheng He}

Key Laboratory of Qinghai-Tibetan Plateau Animal Genetic Resource Reservation and Utilization of Education Ministry, Southwest Minzu University, Chengdu

\section{Yong Wang}

Key Laboratory of Qinghai-Tibetan Plateau Animal Genetic Resource Reservation and Utilization of Education Ministry, Southwest Minzu University, Chengdu

Jiangjiang Zhu

Key Laboratory of Qinghai-Tibetan Plateau Animal Genetic Resource Reservation and Utilization of Education Ministry, Southwest Minzu University, Chengdu

\section{Yan Xiong}

Key Laboratory of Qinghai-Tibetan Plateau Animal Genetic Resource Reservation and Utilization of Education Ministry, Southwest Minzu University, Chengdu

\section{Yanyan Li}

Key Laboratory of Qinghai-Tibetan Plateau Animal Genetic Resource Reservation and Utilization of Education Ministry, Southwest Minzu University, Chengdu

\section{Juan Chen}

Key Laboratory of Qinghai-Tibetan Plateau Animal Genetic Resource Reservation and Utilization of Education Ministry, Southwest Minzu University, Chengdu

\section{Yaqiu Lin ( $\square$ linyq1999@163.com )}

Key Laboratory of Qinghai-Tibetan Plateau Animal Genetic Resource Reservation and Utilization of Education Ministry, Southwest Minzu University, Chengdu

\section{Research Article}

Keywords: RNA-seq, Intramuscular adipocyte, Subcutaneous adipocyte, Goat, IncRNA, mRNA

Posted Date: June 11th, 2021

DOl: https://doi.org/10.21203/rs.3.rs-597449/v1

License: (a) This work is licensed under a Creative Commons Attribution 4.0 International License. Read Full License 


\section{Abstract}

Background: Goats are popular in China because of their superior meat quality, delicate flesh, and unique flavor. Long noncoding RNAs (IncRNAs) play important roles in transcriptional and post-transcriptional regulation of gene expression. However, the effects of IncRNAs on the meat quality of goat hasn't been fully elucidated yet.

Results: In this investigation, we performed RNA-Seq analysis of intramuscular and subcutaneous adipocytes from Jianzhou Daer goat before and after differentiation, including both intramuscular preadipocytes (IMPA) vs intramuscular adipocytes (IMA) and subcutaneous preadipocytes (SPA) vs subcutaneous adipocytes (SA). A total of $289.49 \mathrm{G}$ clean reads and 12,519 IncRNAs were obtained from 20 samples. In total, 4,121 differentially expressed RNAs (388 miRNAs, 182 IncRNAs and 3,551 mRNAs) were identified by pairwise comparison. There were 135 differentially expressed IncRNAs specific to intramuscular adipocytes, 39 DELs specific to subcutaneous adipocytes, and 8 DELs common to both adipocytes in these 182 DELs. Some well-known and novel pathways associated with preadipocyte differentiation were identified: fat acid metabolism, TGF-beta signaling pathway and PI3K-Akt signaling pathway. We also identified hub miRNAS in both types of fat cells and visualized them in Cytoscape.

Conclusions: Our analysis revealed the unique and common IncRNA-miRNA-mRNA networks of two kinds of adipocytes. Several IncRNAs that regulate goat meat quality were screened out, such as XR_001918647.1, XR_001917728.1, XR_001297263.2 and LNC_004191. Our study utilized RNA-seq analysis to predict the functions of IncRNA on goat meat quality. Furthermore, our findings of IncRNAmiRNA-mRNA network, may contribute to a better understanding of the molecular mechanisms underlying in goat meat quality and provide a theoretical basis for further goat molecular breeding.

\section{Background}

Fat is generally divided into subcutaneous fat, intermuscular fat and intramuscular fat. The amount of intermuscular fat is small and its composition is similar to subcutaneous fat, so it is generally considered that fat is mainly divided into subcutaneous fat and intramuscular fat [1]. The distribution of fat in meat animals and the fat content of each part have an important impact on meat production and quality. Subcutaneous fat determines the carcass lean rate to a certain extent. The thicker the fat means the lower the lean meat rate. Intramuscular fat has an important influence on the flavor and tenderness of goat meat. Within a certain range, the quality of meat gradually improves with the increase of intramuscular fat content. One of the current research directions for meat is to study how to regulate the content of intramuscular fat and subcutaneous fat to improve meat quality of goats.

Adipogenesis is a complex process regulated by various transcription factors, non-coding RNA and signal pathways [2]. RNA sequencing (RNA-seq) is a revolutionary tool to identify differentially expressed genes (DEGs) regulating various biological processes. It enables us to discover new genes and therefore to describe unannotated transcriptional activity by identifying numerous noncoding transcripts [3]. Long 
non-coding RNAs (IncRNAs) are non-coding RNAs with a length greater than 200 nucleotides and low protein coding ability. MicroRNAs (miRNAs) are a type of endogenous non-coding RNA with a length of approximately 22 nucleotides. Previous studies have shown that IncRNAs and mRNAs containing the same miRNA binding site can regulate mutual expression levels by competitively binding miRNAs. The recent explosion in knowledge demonstrating the importance of miRNAs and IncRNAs in the regulation of multiple major biological processes, which impacts the development, differentiation, and metabolism have brought these neglected molecular players [4-6]. Some studies have shown that the adipogenic differentiation ability of intramuscular adipocytes is significantly lower than that of subcutaneous adipocytes. The expression of related genes is low, indicating that there are specific regulatory mechanisms for intramuscular fat and subcutaneous fat in animals [7, 8]. In mammals, the differentiation of preadipocytes has been well studied, especially in bovine and porcine [9-13]. Recently, goat meat is gradually welcomed by consumers because of its high protein content, low fat and cholesterol content. Moreover, the consumers demand for goat meat and quality requirements continue to rise $[14,15]$. However, there are few studies on the molecular mechanism of the difference in the deposition of different fat tissues in goats.

Herein, we provided a comprehensive transcriptome profile on intramuscular and subcutaneous adipocytes in before and after differentiation of Jianzhou Daer goat. The results revealed the expression patterns of mRNAs and IncRNAs, which were important in the developmental stages of two different adipocytes. An integrated analysis of differentially expressed IncRNAs (DELs) and mRNAs (DEGs) was performed, and the IncRNA and its target miRNA/mRNA that could potentially regulate the differentiation of intramuscular and subcutaneous preadipocytes were screened through bioinformatics analysis. At the same time, a IncRNA-miRNA-mRNA interaction network was constructed based on miRNAs known to play a role in adipogenesis. The IncRNA that may be combined with miRNA and mRNA was screened out and verified by RT-qPCR technique. The results from the present investigation provided a theoretical basis for in-depth analysis of the regulation mechanism of goat fat cell differentiation and improvement of meat quality in goats.

\section{Results}

\section{Transcript sequencing and assembly}

We established twenty cDNA libraries that represented two different adipocytes: intramuscular preadipocytes (IMPA, 1-5) and intramuscular adipocytes (IMA, 1-5) from the longissimus dorsi of 7-dayold Jianzhou Daer goat, subcutaneous preadipocytes (SPA, 1-5) and subcutaneous adipocytes (SA, 1-5) from the subcutaneous fat of 7-day-old Jianzhou Daer goat. The RNA sequencing obtained a total of $289.49 \mathrm{~Gb}$ of data, with each stage averaging $14.4745 \mathrm{~Gb}$ of data. The Q30 results in each sample were $>91 \%$, and the GC percentage was less than $52 \%$, as listed in Table 1 . More than $47.76 \%$ of the clean reads were perfectly mapped to the goat reference genome (assembly ARS1, https://www.ncbi.nlm.nih.gov/genome /?term = goat), and 44.56 to $87.33 \%$ uniquely mapped reads were obtained from the total mapped reads from the twenty samples (Table 2). 
Finally, 12519 assumed non-coding transcripts were retained by CNCl, CPC2 and PFAM softwares (Fig. 1A), including 16.9\% IncRNAs, 76.1\% intronic IncRNAs, and 7\% anti-sense IncRNAs. In addition, 43767 mRNAs were identified. The expression level of each RNA was standardized to fragments per kilobase of exon model per million mapped reads (FPKM), and it was found that a small part of them was not expressed or was expressed at a relatively low level. The expression levels of a large number of RNAs were mainly between 0.1 and 2 of $\log 10($ FPKM +1$)$, and a small number of genes had very high expression level ( $\log 10|F P K M+1|>2)$ (Fig. 1B). The extremely significant differences of genes were helpful to explore the molecular mechanism of fat deposition in different tissues.

Table 1

Output statistics of the sequencing reads for each sample

\begin{tabular}{|llllllll|}
\hline $\begin{array}{l}\text { Sample } \\
\text { name }\end{array}$ & Raw reads & $\begin{array}{l}\text { Clean } \\
\text { reads }\end{array}$ & $\begin{array}{l}\text { Clean } \\
\text { bases }\end{array}$ & $\begin{array}{l}\text { Error } \\
\text { rate(\%) }\end{array}$ & Q20(\%) & Q30(\%) & $\begin{array}{l}\text { GC } \\
\text { content(\%) }\end{array}$ \\
\hline IMA1 & 106965744 & 104026824 & $15.6 G$ & 0.01 & 97.43 & 93.49 & 46.19 \\
\hline IMA2 & 97739340 & 95783582 & $14.37 G$ & 0.01 & 97.38 & 93.41 & 45.44 \\
\hline IMA3 & 100355022 & 98296238 & $14.74 G$ & 0.02 & 97.28 & 93.19 & 46.19 \\
\hline IMA4 & 87081698 & 85127438 & $12.77 G$ & 0.02 & 97.30 & 93.26 & 45.62 \\
\hline IMA5 & 93900560 & 92052240 & $13.81 G$ & 0.01 & 97.33 & 93.31 & 45.94 \\
\hline IMPA1 & 89914112 & 87780640 & $13.17 G$ & 0.02 & 96.88 & 92.26 & 50.48 \\
\hline IMPA2 & 89869988 & 87544572 & $13.13 G$ & 0.02 & 96.76 & 92.01 & 49.14 \\
\hline IMPA3 & 86513066 & 84676776 & $12.7 G$ & 0.02 & 96.89 & 92.26 & 51.41 \\
\hline IMPA4 & 93072522 & 91173148 & $13.68 G$ & 0.01 & 97.45 & 93.47 & 49.64 \\
\hline IMPA5 & 103727284 & 100918664 & $15.14 G$ & 0.02 & 96.27 & 91.00 & 51.62 \\
\hline SA1 & 102257046 & 96016600 & $14.4 G$ & 0.01 & 97.19 & 93.12 & 45.12 \\
\hline SA2 & 113958516 & 107224614 & $16.08 G$ & 0.01 & 97.21 & 93.11 & 45.29 \\
\hline SA3 & 96569252 & 90603612 & $13.59 G$ & 0.02 & 97.01 & 92.44 & 44.74 \\
\hline SA4 & 92196036 & 86251102 & $12.94 G$ & 0.02 & 97.24 & 92.92 & 44.74 \\
\hline SA5 & 89102014 & 86443762 & $12.97 G$ & 0.02 & 96.54 & 91.61 & 45.44 \\
\hline SPA1 & 89233018 & 87343234 & $13.1 G$ & 0.02 & 97.03 & 92.56 & 45.46 \\
\hline SPA2 & 112263802 & 105239820 & $15.79 G$ & 0.02 & 97.12 & 92.97 & 45.32 \\
\hline SPA3 & 119992036 & 112810026 & $16.92 G$ & 0.02 & 97.08 & 92.87 & 45.82 \\
\hline SPA4 & 116537456 & 109357518 & $16.4 G$ & 0.02 & 97.18 & 93.04 & 45.78 \\
\hline SPA5 & 128978020 & 121273002 & $18.19 G$ & 0.02 & 97.15 & 93.00 & 45.75 \\
\hline
\end{tabular}


Table 2

Summary of the clean reads alignment to the goat reference genome

\begin{tabular}{|lllll|}
\hline Sample name & Total reads & Total mapped & Multiple mapped & Uniquely mapped \\
\hline IMA1 & 104026824 & $58826296(56.55 \%)$ & $5007777(4.81 \%)$ & $53818519(51.74 \%)$ \\
\hline IMA2 & 95783582 & $52467109(54.78 \%)$ & $3378217(3.53 \%)$ & $49088892(51.25 \%)$ \\
\hline IMA3 & 98296238 & $64127686(65.24 \%)$ & $4344218(4.42 \%)$ & $59783468(60.82 \%)$ \\
\hline IMA4 & 85127438 & $49359285(57.98 \%)$ & $3294364(3.87 \%)$ & $46064921(54.11 \%)$ \\
\hline IMA5 & 92052240 & $53774996(58.42 \%)$ & $3822996(4.15 \%)$ & $49952000(54.26 \%)$ \\
\hline IMPA1 & 87780640 & $80670979(91.9 \%)$ & $6751338(7.69 \%)$ & $73919641(84.21 \%)$ \\
\hline IMPA2 & 87544572 & $70588932(80.63 \%)$ & $6111853(6.98 \%)$ & $64477079(73.65 \%)$ \\
\hline IMPA3 & 84676776 & $79535538(93.93 \%)$ & $7181504(8.48 \%)$ & $72354034(85.45 \%)$ \\
\hline IMPA4 & 91173148 & $78490007(86.09 \%)$ & $6695561(7.34 \%)$ & $71794446(78.75 \%)$ \\
\hline IMPA5 & 100918664 & $96226399(95.35 \%)$ & $8091611(8.02 \%)$ & $88134788(87.33 \%)$ \\
\hline SA1 & 96016600 & $47294011(49.26 \%)$ & $3673053(3.83 \%)$ & $43620958(45.43 \%)$ \\
\hline SA2 & 107224614 & $56076878(52.3 \%)$ & $4502794(4.2 \%)$ & $51574084(48.1 \%)$ \\
\hline SA3 & 90603612 & $45139764(49.82 \%)$ & $3788336(4.18 \%)$ & $41351428(45.64 \%)$ \\
\hline SA4 & 86251102 & $41189983(47.76 \%)$ & $2755466(3.19 \%)$ & $38434517(44.56 \%)$ \\
\hline SA5 & 86443762 & $42725042(49.43 \%)$ & $3277966(3.79 \%)$ & $39447076(45.63 \%)$ \\
\hline SPA1 & 87343234 & $49526419(56.7 \%)$ & $3284941(3.76 \%)$ & $46241478(52.94 \%)$ \\
\hline SPA2 & 105239820 & $57264925(54.41 \%)$ & $3543746(3.37 \%)$ & $53721179(51.05 \%)$ \\
\hline SPA3 & 112810026 & $63555694(56.34 \%)$ & $4360117(3.87 \%)$ & $59195577(52.47 \%)$ \\
\hline SPA4 & 109357518 & $59092897(54.04 \%)$ & $3924824(3.59 \%)$ & $55168073(50.45 \%)$ \\
\hline SPA5 & 121273002 & $64549280(53.23 \%)$ & $4580894(3.78 \%)$ & $59968386(49.45 \%)$ \\
\hline
\end{tabular}

\section{Characteristics of IncRNAs and mRNAs in intramuscular and subcutaneous adipocytes of goats before and after differentiation}

Since most IncRNAs are produced by RNA polymerase II transcription, they have structural features similar to those of mRNAs [16]. Therefore, in order to observe the characteristics of IncRNAs and the 
difference between IncRNAs and mRNAs, we compared the length of IncRNAs and mRNAs, including the number of exons, and the open reading frame (ORF). The results showed that most of IncRNAs tended to be shorter in length, and they contained less exons than mRNAs (Fig. 1C). Also, the length of ORFs in the IncRNAs was shorter than those of the mRNAs (Fig. 1D \& 1E).

\section{Differentially expressed IncRNAs and mRNAs in goat different adipocytes}

The correlation coefficient can represent the degree of similarity between samples. We found that the data between SPA and SA, and between IMPA and IMA were highly correlated in expression (Fig. 2A ). We found 143 IncRNAs and 33258 mRNAs differentially expressed between IMA and IMPA (1451 were upregulated, 1950 were down-regulated), 47 IncRNAs and 1659 mRNAs differentially expressed between SA and SPA (851 were up-regulated, 855 were down-regulated) (Fig. 2B). To further explore the differences in IncRNAs expression between subcutaneous and intramuscular adipocytes at different developmental stages, we performed a clustered heat map on the differentially expressed genes. The results of the cluster analysis showed that distinct IncRNAs expression patterns are associated with the differentiation of both subcutaneous and intramuscular adipocytes in goats (Fig. 2C).

\section{Function prediction of IncRNAs and corresponding genes during intramuscular and subcutaneous preadipocyte differentiation}

LncRNAs not only can regulate the expression of neighboring protein-coding genes through a cis mechanism $[17,18]$, but also regulate the expression of genes located on other chromosomes via a trans mechanism $[19,20]$. In this study, bioinformatic analysis was used to predict the potential target genes of DELs via trans. The absolute value of Pearson's correlation coefficient was set as greater than 0.95 . There were 39012 IncRNA-mRNA relationship pairs. Among them, LNC_004374, LNC_007272, LNC_010037, LNC_004066, LNC_010143 and other IncRNAs can target genes related to adipocyte differentiation or lipid metabolism, CD36 [21], FABP3 [22], FGF11 [23], FOXO6 [24], SMAD1 [25], TGFB226, FGFR2 [27]. The results are shown in Table 3.

We drew Venn diagrams (Fig. 3A) to visualize the number of differential IncRNAs that are common versus unique to the two adipocyte differential differentiation processes. Through the use of Goseq, we compare the GO classifications of DELs (adjusted $P<0.05$ ) [28]. The DELs target genes are enriched in biological process (BP), cellular component (CC) and molecular function (MF)(Table 4). Unique DELs target genes of goat intramuscular adipocytes before and after differentiation are mainly enriched in binding(Fig. 3B), and the unique DELs target genes of subcutaneous adipocytes are mainly enriched in glucose metabolism and chemokine(Fig. 3C), while the shared DELs target genes are mainly enriched in binding(Fig. 3D).

The KEGG annotation results of the differentially expressed target genes of IncRNAs are classified according to the pathway types of the KEGG database. As shown in the Fig. 3E, the unique DELs target 
genes of intramuscular adipocytes before and after differentiation are most significantly enriched in hypertrophic cardiomyopathy (HCM), dilated cardiomyopathy, focal adhesion, arrhythmogenic right ventricular cardiomyopathy (ARVC), ECM-receptor interaction, proteoglycans in cancer and cardiac muscle contraction $(P<0.05)$. In addition, the analyzed genes also was enriched in fat acid metabolism and TGF-beta signaling pathway, which are related to adipocyte formation. The unique DELs target genes of subcutaneous adipocytes before and after differentiation are most significantly enriched in biosynthesis of amino acids, glycolysis / Gluconeogenesis, carbon metabolism, valine, leucine and isoleucine degradation, histidine metabolism, fatty acid degradation, melanoma, fatty acid metabolism $(P$ $<0.05$ ), among which fatty acid degradation, fatty acid metabolism, TGF-beta signaling pathway, PI3KAkt signaling pathway have a significant impact on the adipogenesis(Fig. 3F). The shared DELs target genes are most significantly enriched in biosynthesis of amino acids, carbon metabolism, glycolysis / gluconeogenesis and alzheimer's disease $(P<0.05)$ (Fig. 3G). 
Table 3

Part of IncRNA and its target gene related to adipogenesis

\begin{tabular}{|c|c|c|}
\hline $\begin{array}{l}\text { Target } \\
\text { gene }\end{array}$ & Description & IncRNA \\
\hline \multirow[t]{4}{*}{$C D 36$} & \multirow{4}{*}{$\begin{array}{l}\text { CD36 } \\
\text { molecule }\end{array}$} & LNC_004374 LNC_007272 LNC_010037 LNC_004066 LNC_010143 \\
\hline & & LNC_003287 LNC_000379 LNC_000462 LNC_005589 LNC_002362 \\
\hline & & LNC_011316 LNC_011269 LNC_001565 LNC_006348 LNC_002032 \\
\hline & & LNC_000679 LNC_002558 LNC_011971 LNC_009810 XR_001919420.1 \\
\hline \multirow[t]{3}{*}{ FABP3 } & \multirow{3}{*}{$\begin{array}{l}\text { fatty acid } \\
\text { binding } \\
\text { protein } 3\end{array}$} & XR_001917639.1 LNC_010010 XR_309714.3 XR_001918356.1 \\
\hline & & LNC_005049 LNC_008023 LNC_007295 XR_001919935.1 \\
\hline & & XR_001918074.1 LNC_009465 XR_001917605.1 LNC_004888 \\
\hline FGF11 & $\begin{array}{l}\text { fibroblast } \\
\text { growth } \\
\text { factor } 11\end{array}$ & LNC_009670 LNC_011765 LNC_011764 LNC_010048 \\
\hline \multirow[t]{3}{*}{ FOXO6 } & \multirow[t]{3}{*}{$\begin{array}{l}\text { forkhead } \\
\text { box } 06\end{array}$} & $\begin{array}{l}\text { XR_001917700.1 XR_001918450.1 XR_001917557.1 XR_001919481.1 } \\
\text { XR_001919828.1 LNC_007210 LNC_007370 LNC_006351 LNC_007188 } \\
\text { LNC_006638 LNC_009693 LNC_010010 LNC_011790 LNC_002248 }\end{array}$ \\
\hline & & LNC_000560 XR_001917649.1 XR_001918167.1 LNC_006658 \\
\hline & & LNC_008810 \\
\hline \multirow[t]{2}{*}{ SMAD1 } & \multirow{2}{*}{$\begin{array}{l}\text { SMAD } \\
\text { family } \\
\text { member } 1\end{array}$} & LNC_009792 LNC_007731 LNC_000706 LNC_008467 LNC_006192 \\
\hline & & LNC_004878 \\
\hline \multirow[t]{3}{*}{ TGFB2 } & \multirow{3}{*}{$\begin{array}{l}\text { transforming } \\
\text { growth } \\
\text { factor beta } 2\end{array}$} & LNC_011039 XR_001917557.1 XR_001917639.1 LNC_007210 \\
\hline & & LNC_007370 LNC_010010 LNC_005049 XR_001917649.1 \\
\hline & & XR_001918074.1 LNC_000622 LNC_009465 XR_001917605.1 \\
\hline \multirow[t]{6}{*}{ FGFR2 } & \multirow{6}{*}{$\begin{array}{l}\text { fibroblast } \\
\text { growth } \\
\text { factor } \\
\text { receptor } 2\end{array}$} & LNC_004374 LNC_000260 LNC_007272 LNC_001963 LNC_006095 \\
\hline & & LNC_004066 LNC_010140 LNC_001914 LNC_003262 LNC_006919 \\
\hline & & LNC_007053 LNC_000379 LNC_006649 LNC_009821 LNC_003963 \\
\hline & & LNC_002980 LNC_010402 LNC_011269 LNC_012328 LNC_000820 \\
\hline & & LNC_006348 LNC_002032 LNC_009618 LNC_004423 LNC_002558 \\
\hline & & LNC_009048 LNC_011971 LNC_009810 LNC_001111 \\
\hline
\end{tabular}


Table 4

$\mathrm{GO}$ enrichment analysis of the target genes of IncRNAs in intramuscular and subcutaneous adipocytes

\begin{tabular}{|llll|}
\hline & IMA VS IMPA & SA VS SPA & Common \\
\hline biological process & 30 & 28 & 0 \\
\hline cellular component & 148 & 0 & 0 \\
\hline molecular function & 1882 & 12 & 11 \\
\hline
\end{tabular}


Table 5

Node degree of mRNA-miRNA-IncRNA regualatory network

\begin{tabular}{|c|c|c|c|c|c|c|}
\hline $\begin{array}{l}\text { Factor } \\
\text { type }\end{array}$ & $\begin{array}{l}\text { Intramuscular } \\
\text { unique }\end{array}$ & Degree & $\begin{array}{l}\text { Subcutaneous } \\
\text { unique }\end{array}$ & Degree & Common & Degree \\
\hline miRNA & chi-novel-miR-174 & 172 & chi-novel-miR-184 & 92 & $\begin{array}{l}\text { chi-novel-miR- } \\
302\end{array}$ & 35 \\
\hline miRNA & chi-novel-miR-29 & 151 & chi-novel-miR-183 & 92 & $\begin{array}{l}\text { chi-novel-miR- } \\
29\end{array}$ & 34 \\
\hline miRNA & chi-novel-miR-69 & 126 & chi-novel-miR-182 & 92 & $\begin{array}{l}\text { chi-novel-miR- } \\
69\end{array}$ & 31 \\
\hline miRNA & chi-novel-miR-68 & 126 & chi-novel-miR-20 & 63 & $\begin{array}{l}\text { chi-novel-miR- } \\
68\end{array}$ & 31 \\
\hline miRNA & chi-novel-miR-67 & 126 & chi-novel-miR-302 & 59 & $\begin{array}{l}\text { chi-novel-miR- } \\
67\end{array}$ & 31 \\
\hline miRNA & chi-novel-miR-407 & 115 & chi-novel-miR-174 & 57 & $\begin{array}{l}\text { chi-novel-miR- } \\
174\end{array}$ & 28 \\
\hline miRNA & chi-novel-miR-207 & 115 & chi-novel-miR-69 & 57 & $\begin{array}{l}\text { chi-novel-miR- } \\
194\end{array}$ & 27 \\
\hline miRNA & chi-novel-miR-364 & 115 & chi-novel-miR-68 & 57 & $\begin{array}{l}\text { chi-novel-miR- } \\
193\end{array}$ & 27 \\
\hline miRNA & chi-novel-miR-362 & 114 & chi-novel-miR-67 & 57 & $\begin{array}{l}\text { chi-novel-miR- } \\
51\end{array}$ & 25 \\
\hline miRNA & chi-novel-miR-20 & 113 & chi-novel-miR-29 & 54 & $\begin{array}{l}\text { chi-novel-miR- } \\
50\end{array}$ & 25 \\
\hline miRNA & chi-novel-miR-308 & 111 & chi-novel-miR-335 & 53 & $\begin{array}{l}\text { chi-novel-miR- } \\
49\end{array}$ & 25 \\
\hline miRNA & chi-novel-miR-307 & 111 & chi-novel-miR-244 & 53 & $\begin{array}{l}\text { chi-novel-miR- } \\
48\end{array}$ & 25 \\
\hline miRNA & chi-novel-miR-306 & 111 & chi-novel-miR-243 & 53 & $\begin{array}{l}\text { chi-novel-miR- } \\
20\end{array}$ & 24 \\
\hline miRNA & chi-novel-miR-194 & 108 & chi-novel-miR-407 & 47 & $\begin{array}{l}\text { chi-novel-miR- } \\
185\end{array}$ & 24 \\
\hline miRNA & chi-novel-miR-193 & 108 & chi-novel-miR-207 & 47 & $\begin{array}{l}\text { chi-novel-miR- } \\
184\end{array}$ & 24 \\
\hline miRNA & chi-novel-miR-335 & 106 & chi-novel-miR-162 & 46 & $\begin{array}{l}\text { chi-novel-miR- } \\
183\end{array}$ & 24 \\
\hline miRNA & chi-novel-miR-363 & 106 & chi-novel-miR-194 & 46 & $\begin{array}{l}\text { chi-novel-miR- } \\
182\end{array}$ & 24 \\
\hline
\end{tabular}




\begin{tabular}{|lllllll|}
\hline $\begin{array}{l}\text { Factor } \\
\text { type }\end{array}$ & $\begin{array}{l}\text { Intramuscular } \\
\text { unique }\end{array}$ & Degree & $\begin{array}{l}\text { Subcutaneous } \\
\text { unique }\end{array}$ & Degree & Common & Degree \\
\hline miRNA & chi-novel-miR-200 & 94 & chi-novel-miR-193 & 46 & $\begin{array}{l}\text { chi-novel-miR- } \\
4\end{array}$ & 23 \\
\hline miRNA & chi-novel-miR-199 & 89 & chi-novel-miR-292 & 46 & $\begin{array}{l}\text { chi-novel-miR- } \\
335\end{array}$ & 21 \\
\hline miRNA & chi-novel-miR-334 & 88 & chi-novel-miR-4 & 41 & $\begin{array}{l}\text { chi-novel-miR- } \\
384\end{array}$ & 20 \\
\hline
\end{tabular}

\section{Construction of Regulation Networks for adipocytes in goats}

In the previous study, we obtained 146 differentially expressed miRNAs (DEMs) unique to intramuscular adipocytes, 159 (DEMs) unique to subcutaneous adipocytes, and 83 (DEMs) shared by two adipocytes (Fig. 4A). After targeted binding prediction, 306571 mRNAs and 32,029 IncRNAs were found to have potential targeted binding relationships with DEMs. Combined with the sequenced intramuscular adipocyte-specific 2724 DEGs and 135 DELs, 6572 miRNA-mRNA relationship pairs and 1240 miRNAIncRNA relationship pairs were obtained (Fig. 4B). The 1125 DEGs and 39 DELs unique to subcutaneous adipocytes were combined to obtain 3287 miRNA-mRNA relationship pairs and 307 miRNA-IncRNA relationship pairs (Fig. 4B). At the same time, the intersection with a total of 412 DEGs and 8 DELs yielded 1681 miRNA-mRNA relationship pairs and 52 miRNA-IncRNA relationship pairs. The IncRNAmiRNA-mRNA interaction network was constructed by Cytoscape software, and the top 20 miRNAs were selected after calculating the degree value of each factor(Table 5). Among them, we found miR-20, miR194, miR-335, miR-363, miR-200, miR-199, and miR-302 related to fat formation, thereby, we constructed a ceRNA network view. As shown in the Fig. 5A, the unique IncRNA-miRNA-mRNA network of intramuscular adipocytes includes 30 IncRNAs, 6 miRNAs and 426 mRNAs, and the IncRNA-miRNA-mRNA network unique to subcutaneous adipocytes includes 8 IncRNAs, 4 miRNAs and 182 mRNAs (Fig. 5B). Whereas, two types of adipocyte-common IncRNA-miRNA-mRNA networks include 1 IncRNA, 4 miRNAs and 96 mRNAs(Fig. 5C).

\section{Verification of IncRNA expression profiles using qRT-PCR}

To verify the reliability of RNA-seq results, 7 candidate IncRNAs were randomly selected from the DELs obtained from the screening, and UXT was used as an internal reference for qRT-PCR analysis. The results showed that XR_001917557.1, and LNC_004191 were significantly down-regulated in expression in intramuscular adipose tissue. Whereas, the XR_001918647.1, XR_001917728.1 were significantly upregulated in expression in intramuscular adipose tissue. XR_001295810.1, XR_001917637.1 and XR_001297263.2 were significantly down-regulated expression in subcutaneous adipose tissue, and the LNC_004191 was significantly up-regulated expression in subcutaneous adipose tissue, These results were consistent with the trend of RNA-seq, indicating the credibility of the RNA-seq results(Fig. 6). 


\section{Table 6}

Primer sequences of IncRNA amplified by qRT-PCRTable 6

Primer sequences of IncRNA amplified by qRT-PCR

\begin{tabular}{|c|c|c|c|}
\hline Gene name & Primer sequence & Annealing $\left({ }^{\circ} \mathrm{C}\right)$ & Amplicon size(bp) \\
\hline \multirow[t]{2}{*}{ XR_001917557.1 } & TCCATTTTGCCGCAGTGTTC & \multirow[t]{2}{*}{60} & \multirow[t]{2}{*}{167} \\
\hline & GAAATGCACACGGCAGAGAC & & \\
\hline \multirow[t]{2}{*}{ XR_001918647.1 } & AGCTTGGGAGATGCACAAAA & \multirow[t]{2}{*}{60} & \multirow[t]{2}{*}{87} \\
\hline & GCCAGCATATTGGACACCCTT & & \\
\hline \multirow[t]{2}{*}{ XR_001917728.1 } & СTCTGTGGGCGATGACGAAG & \multirow[t]{2}{*}{60} & \multirow[t]{2}{*}{153} \\
\hline & TCTCCATCACACCGGACCAT & & \\
\hline \multirow[t]{2}{*}{ LNC_004191 } & AGGAATGGAAAGTGAACCAGGG & \multirow[t]{2}{*}{60} & \multirow[t]{2}{*}{80} \\
\hline & AGCTGTGTTCCTCCСCTACC & & \\
\hline \multirow[t]{2}{*}{ XR_001295810.1 } & AAGCAAACGGTGTCTGGGG & \multirow[t]{2}{*}{60} & \multirow[t]{2}{*}{81} \\
\hline & AGAGCAATGGTCAGCTTGGA & & \\
\hline \multirow[t]{2}{*}{ XR_001917637.1 } & TGGGCAAGTGAGGGTCTCC & \multirow[t]{2}{*}{60} & \multirow[t]{2}{*}{80} \\
\hline & СССТАСАAGССТСТTСТССАТС & & \\
\hline \multirow[t]{2}{*}{ XR_001297263.2 } & CACAGGGTGAATGACTTGGG & \multirow[t]{2}{*}{60} & \multirow[t]{2}{*}{166} \\
\hline & AATAGGGTGCTTGCAGGTAGG & & \\
\hline \multirow[t]{2}{*}{ UXT } & GCAAGTGGATTTGGGCTGTAAC & \multirow[t]{2}{*}{60} & \multirow[t]{2}{*}{180} \\
\hline & ATGGAGTCCTTGGTGAGGTTGT & & \\
\hline
\end{tabular}

\section{Discussion}

The distribution and deposition of adipose tissue in different parts of the body are the key factors affecting carcass quality and meat flavor. Subcutaneous fat mainly affects carcass quality. Intramuscular fat (IMF) is the material basis of marbling, and an important factor affecting meat flavor. A large number of studies have shown that IMF is directly involved in the formation of meat tenderness, juiciness and flavor $[29,30]$. Goat is an indispensable animal in China's agricultural production, and the molecular regulation mechanism of its lipid deposition has not been fully elucidated yet. 
LncRNA is a kind of noncoding RNA longer than $200 \mathrm{nt}$, which has attracted substantial attention in the last few years. Studies have shown that IncRNAs regulate metabolic tissue development and function, including adipogenesis, hepatic lipid metabolism, islet function, and energy balance [31-35]. Despite the fact that many studies have indicated the importance of IncRNAs in different tissues, little is known about their biological function in goat fat deposition, especially in the differentiation of goat intramuscular and subcutaneous preadipocytes. To the best of our knowledge, our study is the first to screen for IncRNAs and mRNAs regulating goat preadipocyte differentiation by sequencing and annotating the transcriptome of intramuscular and subcutaneous preadipocytes. A total of $1,118,110,544$ reads were successfully mapped to the goat reference genome assembly. We identified 12,519 IncRNAs. The average sequence length of IncRNAs was shorter than that of mRNAs, and the number of exons was less than that of mRNAs, with the ORF length being shorter than that of mRNAs. Our results indicated that the predicted IncRNAs were shorter with fewer exons than mRNAs, which are in agreement with the those reproted in previous studies [36-38]. The Pearson correlation $\left(R^{2}\right)$ of each sample is greater than 0.8 , which indicated that our experiment was reliable and the sample selection was reasonable.

LncRNA functions by regulating mRNA. At present, the mechanism of interaction between IncRNA and mRNA is not clear. We predict the biological function of IncRNAs through its co-expression with protein coding genes. Consequently, we found that many target genes of DELs were also differentially expressed in goat intramuscular and subcutaneous preadipocytes. This suggested that IncRNAs may function through complementary target genes, which can play critical roles in the differentiation of goat intramuscular and subcutaneous preadipocytes. For example, SMAD1 is a target gene of the differentially expressed IncRNAs LNC_009792, LNC_007731, LNC_000706, LNC_008467, LNC_006192 and LNC_004878, and it has been reported to regulate the differentiation of preadipocytes [39]. These findings suggest that these IncRNAs might be involved in the differentiation of intramuscular preadipocytes by affecting the expression of SMAD1. However, there is no DEGs in the differentiation process of subcutaneous preadipocytes in our selected fat development related genes, so we speculate that the network regulating intramuscular adipogenesis is more complex than subcutaneous fat. The higher number of DELs, DEMs and DEGs in IMF than that of subcutaneous fat also supported this, which is consistent with the fact that intramuscular preadipocytes have stronger ability to deposit fat than that of subcutaneous preadipocytes [40].

To explore the similarities and differences of different adipocytes, DELs target genes (IMPA vs IMA and SPA vs SA ) were subjected to GO and KEGG pathway enrichment analyses. We found that few common term was found between the IMPA vs IMA and SPA vs SA comparisons. Several pathways involved in preadipocyte differentiation were previously identified, including the TGF- $\beta$ signaling pathway(IMF and subcutaneous fat) [41], PI3K/AKT signaling pathway (subcutaneous fat) [42], and arachidonic acid metabolism(subcutaneous fat) [43]. For example, the LncRNA GAS5 inhibits lipogenesis in 3T3-L1 cells through the miR-21a-5p / PTEN signaling pathway [44]. FDNCR1 affects porcine lipogenesis by competitively binding miR-204 to regulate the TGF- $\beta$ pathway [45]. However, for some pathways identified here, their involvement in the goat preadipocyte differentiation process is being reported for the first time. 
Interestingly, in the pathway analysis, we found that the components of two pathways, fatty acid metabolism(IMF and subcutaneous fat) and fatty acid degradation (subcutaneous fat), which have been reported to be involved in lipid metabolism, and were enriched in the entire process of differentiation of intramuscular and subcutaneous preadipocytes $[46,47]$. The common enrichment pathways during differentiation of both adipocytes involve amino acid metabolism, gluconeogenesis and carbohydrate metabolism, suggesting that IMF and subcutaneous fat are largely different in differentiation pathways and lipid metabolism pathways, while there are similarities in communication with other metabolic pathways. In addition to the specific pathways of the two adipocytes, there are also differences in the common components of the two pathways. Just as IMF is enriched in 19 target genes of TGF- $\beta$ signaling pathway, 8 target genes of fatty acid metabolism, and subcutaneous fat is enriched in 8 and 7 targat genes. Here, we hypothesize that there are differences in the pathways regulating intramuscular and subcutaneous adipose differentiation, and that there are differences in the downstream target genes in the same pathways, which indirectly demonstrates that gene expression is tissue-specific in goats.

To date, many genes have been reported to regulate the differentiation of preadipocytes. However, few studies have been conducted on the roles of IncRNAs in intramuscular and subcutaneous preadipocytes differentiation. The molecular and cellular mechanisms regulating goat preadipocytes differentiation are thus still poorly understood. Here, we constructed a miRNA-IncRNA-mRNA interaction network, and calculated the degree (the number of times each factor interacts with other factors) of each factor through centerscape. We selected the top 20 miRNAs in the dgree, and found that miR-20 [48], miR-194 [49], miR-335 [50], miR-363 [51], miR-200 [52], miR-199 [53], and miR-302 [54] were related to fat development, and visualized them in Cytoscape. We identified a number of highly connected IncRNAs and mRNAs in the three modules, including the two kinds of adipocytes are unique and common. For example, XM_005693834.3(ACLY) [55] and XM_013975359.2 (ANGPT2) [56] are unique to IMF, and XM_018056618.1(MEDAG) [57] and XM_005678357.3(PLPP3) [58] are unique to subcutaneous fat, whereas, XM_018040030.1 (CAPN10) [59] and XM_018050348.1 (TGFB1) [60] are shared by the two kinds of preadipocytes in differentiation processes. Seven DELs from the IMF vs subcutaneous fat comparison were validated by qRT-PCR technique and the results were in excellent generally agreement with the RNA-seq findings. This suggests that our RNA-seq findings are reliable.

In conclusion, we first generated the expression profiles of IncRNAs from intramuscular and subcutaneous adipocytes of Jianzhou Daer goat (IMA vs IMPA and SA vs SPA) based on RNA-Seq technique. We found that the number of IncRNAs regulating IMF differentiation was more than that of subcutaneous adipocytes. Our results suggest that those IncRNAs might play important roles in meat quality. Collectively, this study takes the first step toward understanding the molecular mechanisms underlying variations in goat meat quality. Also, our results provided a theoretical basis for molecular breeding to improve the meat quality in goats.

\section{Materials And Methods}

\section{Experimental animals and sample collection}


All experimental procedures were reviewed and approved by the Institutional Animal Care and Use Committee, Southwest Minzu University. Also, all the experiments complied with the requirements of the directory of the Ethical Treatment of Experimental Animals of China.

The 7-day-old male Jianzhou Daer goat (Capra hircus) $(n=5)$ was purchased from Sichuan Jianyang Dageda Aminal Husbandry Co., Ltd (Sichuan, China), being euthanized by bloodletting. The longissimus dorsi and subcutaneous fat were excised from the goats and minced. The isolation and culture of goat intramuscular preadipocytes was performed as described assay by Xu et al. [61]. The subcutaneous adipocytes were isolated by using Type I collagenase(Sigma, St. Louis, MO, USA). When the cell confluence reaches $80 \%$, we discarded the medium and added appropriate amount of trypsin (Hyclone, Logan, UT, USA), and the cells were digested at $37^{\circ} \mathrm{C}$ for $1 \mathrm{~min}$. And then, the cells were harvested in a centrifuge tube, followed by a centrifuge at $800 \mathrm{rpm} / \mathrm{min}$ for $3 \mathrm{~min}$ to obtain cell pellet. The collected cells were re-suspended for subsequent experiments. The cells of passage 3 , were used for experimental treatment. The cells were coaxed into differentiating using oleic acid induction solution $(50 \mu \mathrm{mol} / \mathrm{L})$ (Sigma, St. Louis, MO, USA), and harvested after induction for 0 and $3 d[62,63]$. These cell samples were named intramuscular preadipocytes (IMPA), subcutaneous preadipocytes (SPA), intramuscular adipocytes (IMA) and subcutaneous adipocytes (SA), respectively, and 5 biological replicates were set for each group.

\section{Total RNA extraction and sequencing}

A total of 20 cell samples were successfully collected. Total RNA was extracted using Trizol reagent (Takara, Dalian, China). RNA quality was determined using NanoPhotometer spectrophotometer and Agilent 2100 bioanalyzer, which analyzes the integrity of the RNA. The IncRNA library is constructed using a chain-specific library. The method for synthesizing the first strand of CDNA by reverse transcription is the same as the normal method of NEB library construction. The difference is that when the second strand is synthesized, dTTP in dNTPs is replaced by dUTP. After that, cDNA end repair, A-tailing, ligation of sequencing adapters, and length screening were also performed, and then the second strand of cDNA containing $U$ was degraded by USER enzyme, and then PCR amplification was performed to obtain a library. Finally, twenty libraries were sequenced at Novogene Co. Ltd. (Beijing, China) on Illumina HiSeq Sequencing System.

\section{Quality control and transcript assembly}

After sequencing, the raw data were stored in fastq format [64]. We removed reads containing connectors, poly-N and low quality from Raw Reads to get clean reads. The Q20, Q30 and GC content of the clean data were calculated [65]. The obtained clean, high-quality data were used for further analyses. The clean, paired-end reads were aligned to the goat genome sequence assembly using HISAT2 [66], and the transcripts were assembled using both Scripture (beta2) [67] and Cufflinks (v2.1.1) [68].

\section{Identification of IncRNAs and their expression analysis}


To ensure the quality of the obtained IncRNAs, three criteria were used to identify the desired IncRNAs in the transcriptome assemblies: 1 ) transcripts with length $>200$ bp and exon number $\geq 2$ were selected; 2 ) Cuffcompare was used to calculate the read coverage of every transcript, and transcripts with an FPKM value(Cuffquant) of more than 0.05 were removed; and 3 ) the coding potential of the transcripts was predicted using the coding potential calculator $(\mathrm{CPC}<1)$ [69], Coding Noncoding Index $(\mathrm{CNCl})[70]$, and Pfam [71] protein domain families to further remove coding genes. Subsequent steps were performed based on the intersection of the results obtained using the twenty databases.

The FPKMs values of IncRNAs and mRNAs in IMPA, IMA, SPA and SA libraries were calculated by StringTie, balltown and Cuffdiff. The transcripts in the 20 libraries were analyzed for differential expression, and the $P$ value was used to screen the DELs and DEGs between two different adipocyte samples. When $P<0.05$, the IncRNAs and mRNAs are considered to be differentially expressed.

\section{Gene functional annotation}

The trans function describes the co-expression relationship between IncRNAs and mRNAs. Pearson correlation coefficient $(R>0.95$ or $R<0.95)$ was calculated by custom scripts. David was used to cluster the target genes among 20 samples for functional enrichment analysis of IncRNA target genes [72]. Pvalue $<0.05$ was set as significant threshold. Go (gene ontology) can enrich and analyze the target genes of DELs. Goseq is used to enrich and analyze the target genes of DELs. $P<0.05$ is considered to be the significant enrichment of GEGs. KEGG is a database (http://www.genome.jp/kegg/) for understanding the advanced functions and utilities of biological systems such as cells, organisms, and ecosystems. We used KOBAS software to detect the pathway enrichment analysis of DELs target genes in the KEGG pathway.

\section{Download of miRNA sequencing data and construction of IncRNA-miRNA-mRNA networks}

The raw data were processed using our previous sequencing to remove adaptor dimers, garbage, low complexity, common RNA families (rRNA, tRNA, snRNA, snoRNA), and repeats. Then we used miRBase to define known miRNAs. Finally, unmapped sequences were predicted using RNAfold software. The edgeR software [73] was used to calculate DEMs, in two adipocytes. The screening criterion for significant differences is P-value < 0.05. miRWalk, The miRanda, RNAhybrid, and Targetscan were used for screening. Then, the intersections of co-expressed IncRNAs, miRNAs, and mRNAs in the 4 programs were used to construct a IncRNA-miRNA-mRNA network.

DELs and DEGs were combined with the target IncRNAs and mRNAs of DEMs respectively to obtain the miRNA-mRNA relationship pair and miRNA-InRNA relationship pair. Finally, the IncRNA-miRNA-mRNA network was visualized using Cytoscape v3.7 software.

\section{Validation of gene expression of by RT-qPCR technique}


Primers were designed using Primer-BLAST on the NCBI website (Table 6). The first CDNA strand was synthesized using the RevertAid First Strand cDNA Synthesis Kit (Thermo, Waltham, MA, USA), in accordance with the user manual. Ubiquitously expressed transcript gene (UXT) was used as a housekeeping gene [74]. The qPCR reaction procedure was composed of four steps, including predegeneration $\left(95^{\circ} \mathrm{C}, 3 \mathrm{~min}\right)$, degeneration $\left(95^{\circ} \mathrm{C}, 10 \mathrm{~s}\right)$, annealing $\left(60^{\circ} \mathrm{C}, 10 \mathrm{~s}\right)$ and extension $\left(72^{\circ} \mathrm{C}, 15 \mathrm{~s}\right)$, of which degeneration, annealing and extension were running for 40 cycles. Quantification of selected gene expression was performed using the comparative threshold cycle $\left(2^{-\triangle \Delta C T}\right)$ method [75].

\section{Declarations}

\section{Acknowledgements}

The authors acknowledge assistance from the goat lipid metabolism research lab.

\section{Authors' contributions}

C.H. Y.X. and Y.L. conceived the research; C.H. performed the experiments; Y.W. and J.Z. shared regents; C.H. and Y.L. analysed the data; C.H. J.C. and Y.L. wrote the paper. All authors read and approved the final manuscript.

\section{Funding}

This work was supported by National Natural Sciences Foundation of China (No. 32072723, 31672395, 31902154) and Fundamental Research Funds for the Central Universities, Southwest Minzu University(2020NYB29).

\section{Availability of data and materials}

The datasets generated during and/or analyses during the current study are available in the article and its additional files.

\section{Declarations}

\section{Ethics approval and consent to participate}

All experimental procedures involving animals were performed in accordance with the guidelines and regulations approved by The Animal Care and Use Committee of the Southwest Minzu University (Chengdu, Sichuan, China). The experiment would be performed under the requirement of Animal Care 
and Use Committee of Southwest Minzu University (No. 18032). This study was carried out in compliance with the ARRIVE guidelines. All goats were humanely sacrificed and all efforts were made to minimize the suffering.

\section{Consent for publication}

Not applicable.

\section{Competing interests}

The authors declare that they have no competing interests.

\section{References}

1. Timón ML, Ventanas J, Carrapiso Al, Jurado A, García C. Subcutaneous and intermuscular fat characterisation of dry-cured Iberian hams. Meat science. 2001; 58(1): 85-91. https://doi. org /10.1016/s0309-1740(00)00136-4.

2. Mattar P, Bravo-Sagua R, Tobar N, Fuentes C, Troncoso R, Breitwieser G, Lavandero S, Cifuentes M. Autophagy mediates calcium-sensing receptor-induced TNFa production in human preadipocytes. Biochimica et biophysica acta. Molecular basis of disease. 2018; 1864(11): 3585-3594. https://doi.org/10.1016/j.bbadis.2018.08.020.

3. Wang Y, Xue S, Liu X, Liu H, Hu T, Qiu X, Zhang J, Lei M. Analyses of Long Non-Coding RNA and mRNA profiling using RNA sequencing during the pre-implantation phases in pig endometrium. Scientific reports. 2016; 6: 20238. https://doi.org/10.1038/srep20238.

4. Wang KC, Chang HY. Molecular mechanisms of long noncoding RNAs. Molecular cell. 2011; 43(6): 904-914. https://doi.org/10.1016/j.molcel.2011.08.018.

5. Huang Y, Shen XJ, Zou Q, Zhao QL. Biological functions of microRNAs. Bioorganicheskaia khimiia. 2010; 36(6): 747-752. https://doi.org/10.1134/ s1068162010060026.

6. Ren H, Wang G, Chen L, Jiang J, Liu L, Li N, Zhao J, Sun X, Zhou P. Genome-wide analysis of long non-coding RNAs at early stage of skin pigmentation in goats (Capra hircus). BMC genomics. 2016; 17: 67. https://doi.org/10.1186/s12864-016-2365-3.

7. Zhou G, Wang S, Wang Z, Zhu X, Shu G, Liao W, Yu K, Gao P, Xi Q, Wang X, Zhang Y, Yuan L, Jiang Q. Global comparison of gene expression profiles between intramuscular and subcutaneous adipocytes of neonatal landrace pig using microarray. Meat science. 2010; 86(2): 440-450. https://doi.org/10.1016/j.meatsci.2010.05.031.

8. Sun WX, Wang HH, Jiang BC, Zhao YY, Xie ZR, Xiong K, Chen J. Global comparison of gene expression between subcutaneous and intramuscular adipose tissue of mature Erhualian pig. 
Genetics and molecular research: GMR. 2013; 12(4): 5085-5101. https://doi.org/10.4238/ 2013.October.29.3.

9. Chen X, Zhou B, Luo Y, Huang Z, Jia G, Liu G, Zhao H. Tissue Distribution of Porcine FTO and Its Effect on Porcine Intramuscular Preadipocytes Proliferation and Differentiation. PloS one. 2016; 11(3): e0151056. https://doi.org/10.1371/journal.pone.0151056.

10. Sun WX, Dodson MV, Jiang ZH, Yu SG, Chu WW, Chen J. Myostatin inhibits porcine intramuscular preadipocyte differentiation in vitro. Domestic animal endocrinology. 2016; 55: 25-31. https://doi.org/10.1016/j.domaniend. 2015.10.005.

11. Dong X, Tang S, Zhang W, Gao W, Chen Y. GPR39 activates proliferation and differentiation of porcine intramuscular preadipocytes through targeting the PI3K/AKT cell signaling pathway. Journal of receptor and signal transduction research. 2016; 36(2): 130-138. https: //doi.org/10.3109/10799893.2015. 1056308.

12. Yonekura S, Hirota S, Miyazaki H, Tokutake Y. Subcellular Localization and Polymorphism of Bovine FABP4 in Bovine Intramuscular Adipocytes. Animal biotechnology. 2016; 27(2), 96-103. https://doi.org/10.1080/ 10495398.2015.1102148.

13. Zappaterra M, Deserti M, Mazza R, Braglia S, Zambonelli P, Davoli R. A gene and protein expression study on four porcine genes related to intramuscular fat deposition. Meat science. 2016; 121: 27-32. https://doi.org/10.1016/j. meatsci.2016.05.007.

14. Ivanovic S, Pavlovic I, Pisinov B. The quality of goat meat and it's impact on human health. Biotechnology in Animal Husbandry. 2016; 32(2): 111-122. https://doi.org/10.2298/BAH160 2111I.

15. Teixeira A, Silva S, Rodrigues S. Advances in Sheep and Goat Meat Products Research. Advances in Food and Nutrition Research. 2019; 87: 305-370. https://doi.org/10.1016/bs.afnr. 2018. 09.002.

16. Gao X, Ye J, Yang C, Zhang K, Li X, Luo L, Ding J, Li Y, Cao H, Ling Y, Zhang X, Liu Y, Fang F, Zhang Y. Screening and evaluating of long noncoding RNAs in the puberty of goats. BMC genomics. 2017; 18(1): 164. https://doi.org/10.1186/s12864-017-3578-9.

17. Bu Q, Hu Z, Chen F, Zhu R, Deng Y, Shao X, Li Y, Zhao J, Li H, Zhang B, Lv L, Yan G, Zhao Y, Cen X. Transcriptome analysis of long non-coding RNAs of the nucleus accumbens in cocaine-conditioned mice. Journal of neurochemistry. 2012; 123(5): 790-799. https://doi. org/10.1111/jnc.12006

18. Han L, Zhang K, Shi Z, Zhang J, Zhu J, Zhu S, Zhang A, Jia Z, Wang G, Yu S, Pu P, Dong L, Kang C. LncRNA profile of glioblastoma reveals the potential role of IncRNAs in contributing to glioblastoma pathogenesis. International journal of oncology. 2012; 40(6): 2004-2012. https://doi.org/10.3892/ ijo.2012.1413.

19. Cai B, Li Z, Ma M, Wang Z, Han P, Abdalla BA, Nie Q, Zhang X. LncRNA-Six1 Encodes a Micropeptide to Activate Six 1 in Cis and Is Involved in Cell Proliferation and Muscle Growth. Frontiers in physiology. 2017; 8: 230. https://doi.org/10.3389/fphys.2017.00230.

20. Yang L, Yi K, Wang H, Zhao Y, Xi M. Comprehensive analysis of IncRNAs microarray profile and mRNA-IncRNA co-expression in oncogenic HPV-positive cervical cancer cell lines. Oncotarget. 2016; 7(31): 49917-49929. https://doi.org/10.18632/oncotarget.10232. 
21. Lewis G. Lipid metabolism. Current opinion in lipidology. 2006; 17(2): 205-208. https://doi.org/10.1097/01.mol.0000217906.36057.2b.

22. Nakamura Y, Sato T, Shiimura Y, Miura Y, Kojima M. FABP3 and brown adipocyte-characteristic mitochondrial fatty acid oxidation enzymes are induced in beige cells in a different pathway from UCP1. Biochemical and biophysical research communications. 2013;; 441(1):42-46. https://doi.org/10.1016/ j.bbrc.2013.10.014.

23. Lee KW, Jeong JY, An YJ, Lee JH, Yim H-S. FGF11 influences 3T3-L1 preadipocyte differentiation by modulating the expression of PPARy regulators. FEBS Open Bio. 2019; 9(4):769-780. https://doi.org/10.1002/2211-5463.12619.

24. Lee $\mathrm{S}$, Dong HH. FoxO integration of insulin signaling with glucose and lipid metabolism. $J$ Endocrinol. 2017; 233(2): R67-R79. https://doi.org/10.1530/JOE-17-0002.

25. Shin S, Seong JK, Bae YS. Ahnak stimulates BMP2-mediated adipocyte differentiation through Smad1 activation. Obesity (Silver Spring). 2016; 24(2): 398-407. https://doi.org/ 10.1002/oby.21367.

26. Takahashi H, Alves CRR, Stanford KI, Middelbeek RJW, Pasquale N, Ryan RE, Xue R, Sakaguchi M, Lynes MD, So K, Mul JD, Lee M-Y, Balan E, Pan H, Dreyfuss JM, Hirshman MF, Azhar M, Hannukainen JC, Nuutila P, Kalliokoski KK, Nielsen S, Pedersen BK, Kahn C R, Tseng Y-H, Goodyear LJ. TGF- $\beta 2$ is an exercise-induced adipokine that regulates glucose and fatty acid metabolism. Nat Metab. 2019; 1(2): 291-303. https://doi.org/10.1038/s42255-018-0030-7.

27. Fischer $C$, Seki T, Lim S, Nakamura M, Andersson P, Yang Y, Honek J, Wang Y, Gao Y, Chen F, Samani $\mathrm{N}$ J, Zhang J, Miyake M, Oyadomari S, Yasue A, Li X, Zhang Y, Liu Y, Cao Y. A miR-327-FGF10-FGFR2mediated autocrine signaling mechanism controls white fat browning. Nat Commun. 2017; 8(1): 2079-2079. https://doi.org/10.1038/s41467-017-02158-z.

28. Young MD, Wakefield MJ, Smyth GK, Oshlack A. Gene ontology analysis for RNA-seq: accounting for selection bias. Genome biology. 2010; 11(2): R14. https://doi.org/10.1186/gb-2010-11-2-r14.

29. Van L, Stevens SG, Stalder KJ. The influence of ultimate $\mathrm{pH}$ and intramuscular fat content on pork tenderness and tenderization. Journal of Animal Science. 2001; 79: 392-397. https:// doi.org/10.2527/2001.792392x.

30. Suzuki K, Irie M, Kadowaki H, Shibata T, Kumagai M, Nishida A. Genetic parameter estimates of meat quality traits in Duroc pigs selected for average daily gain, longissimus muscle area, backfat thickness, and intramuscular fat content. Journal of Animal Science. 2005; 83: 2058-2065. https://doi.org/10.2527/2005.8392058x.

31. Alvarez-Dominguez JR, Bai Z, Xu D, Yuan B, Lo KA, Yoon MJ, et al. De Novo Reconstruction of Adipose Tissue Transcriptomes Reveals Long Non-coding RNA Regulators of Brown Adipocyte Development. Cell Metab. 2015; 21(5):764 \pm 76. https://doi.org/ 10.1016/j.cmet.2015.04.003.

32. Chen J, Cui X, Shi C, Chen L, Yang L, Pang L, et al. Differential IncRNA expression profiles in brown and white adipose tissues. Molecular genetics and genomics: MGG. 2015; 290(2):699 \pm 707. https://doi.org/10.1007/s00438-014-0954-x. 
33. Luan A, Paik KJ, Li J, Zielins ER, Atashroo DA, Spencley A, et al. RNA Sequencing for Identification of Differentially Expressed Noncoding Transcripts during Adipogenic Differentiation of Adipose-Derived Stromal Cells. Plastic and reconstructive surgery. 2015; 136(4):752 \pm 63. https://doi.org/10.1097/PRS.0000000000001582.

34. You LH, Zhu LJ, Yang L, Shi CM, Pang LX, Zhang J, et al. Transcriptome analysis reveals the potential contribution of long noncoding RNAs to brown adipocyte differentiation. Molecular genetics and genomics: MGG. 2015; 290(5):1659 — 71. https://doi.org/10.1007 /s00438-015-1026-6.

35. Zhao XY, Lin JD. Long Noncoding RNAs: A New Regulatory Code in Metabolic Control. Trends in biochemical sciences. 2015; 40(10):586 \pm 96. https://doi.org/10.1016/j.tibs. 2015.08.002.

36. Wang Y, Xue S, Liu X, Liu H, Hu T, Qiu X, et al. Analyses of Long Non-Coding RNA and mRNA profiling using RNA sequencing during the pre-implantation phases in pig endometrium. Scientific reports. 2016; 6:20238. https://doi.org/10.1038/srep20238.

37. Trapnell C, Williams BA, Pertea G, Mortazavi A, Kwan G, van Baren MJ, et al. Transcript assembly and quantification by RNA-Seq reveals unannotated transcripts and isoform switching during cell differentiation. Nat Biotechnol. 2010; 28(5):511 \pm 5. https://doi.org/ 10.1038/nbt.1621.

38. Ran M, Chen B, Li Z, et al. Systematic Identification of Long Non-Coding RNAs in Immature and Mature Porcine Testes. Biology of Reproduction. 2016; 94: 77. https://doi.org/ 10.1095/biolreprod.115.136911.

39. Shin S, Seong JK, Bae YS. Ahnak stimulates BMP2-mediated adipocyte differentiation through Smad1 activation. Obesity (Silver Spring). 2016; 24(2): 398-407. https://doi.org/10.1002/oby.21367.

40. Chen J, Dodson MV, Jiang Z. Cellular and molecular comparison of redifferentiation of intramuscular-and visceral-adipocyte derived progeny cells. International Journal of Biological Sciences. 2010; 6:80-88. https://doi.org/10.7150/ijbs.6.129.

41. Stewart A, Guan H, Yang K. BMP-3 promotes mesenchymal stem cell proliferation through the TGFbeta/ activin signaling pathway. Journal of cellular physiology. 2010; 223(3):658 \pm 66 . https://doi.org/10.1002/jcp.22064.

42. Dong X, Tang S, Zhang W, Gao W, Chen Y. GPR39 activates proliferation and differentiation of porcine intramuscular preadipocytes through targeting the PI3K/AKT cell signaling pathway. Journal of receptor and signal transduction research. 2016; 36(2):130 \pm 8 . https://doi.org/10.3109/10799893.2015.

43. Nikolopoulou E, Papacleovoulou G, Jean-Alphonse F, Grimaldi G, Parker MG, Hanyaloglu AC, et al. Arachidonic acid-dependent gene regulation during preadipocyte differentiation controls adipocyte potential. Journal of lipid research. 2014; 55(12):2479 \pm 90. https:// doi.org/10.1194/jlr.M049551.

44. Liu H, et al. Long Noncoding RNA GAS5 Suppresses 3T3-L1 Cells Adipogenesis Through miR-21a5p/PTEN Signal Pathway. DNA Cell Biol. 2018; 37(9): 767-777. https://doi.org/10.1089/dna.2018.4264. 
45. Zhang Z, Meng Y, Gao F, Xiao Y, Zheng Y, Wang H-Q, Gao Y, Jiang H, Yuan B, Zhang J-B. TGF- $\beta 1$ Mediated FDNCR1 Regulates Porcine Preadipocyte Differentiation via the TGF- $\beta$ Signaling Pathway. Animals. 2020; 10(8):1399. https://doi.org/10.3390/ani10081399.

46. Wang Y, Botolin D, Xu J, et al. Regulation of hepatic fatty acid elongase and desaturase expression in diabetes and obesity. J Lipid Res. 2006; 47(9):2028-41. https://doi.org/10.1194/ jlr.M600177JLR200.

47. Jump DB. Fatty acid regulation of hepatic lipid metabolism. Curr Opin Clin Nutr. 2011; 14 (2): 11520. https://doi.org/10.1097/MC0.0b013e328342991c.

48. Wang Q, Li YC, Wang J, Kong J, Qi Y, Quigg RJ, et al. miR-17-92 cluster accelerates adipocyte differentiation by negatively regulating tumor-suppressor Rb2/p130. Proc Natl Acad Sci USA. 2008; 105(8): 2889-94. https://doi.org/10.1073/pnas.0800178105.

49. Jeong BC, Kang IH, Hwang YC, et al. MicroRNA-194 reciprocally stimulates osteogenesis and inhibits adipogenesis via regulating COUP-TFIl expression. Cell Death Dis. 2014; 5: e1532. https://doi.org/10.1038/cddis.2014.485.

50. Fernandez-Hernando C, Suarez Y, Rayner K J, et al. MicroRNAs in lipid metabolism. Curr Opin Lipidol. 2011; 22(2):86-92. https://doi.org/10.1097/MOL.0b013e3283428d9d.

51. Chen L, Cui JH, Hou J, et al. A novel negative regulator of adipogenesis: microRNA-363. Stem Cells. 2014; 32(2): 510-520. https://doi.org/10.1002/stem.1549.

52. Kennell JA, Gerin I, MacDougald OA, Candigan KM. The microRNA miR-8 is a conserved negative regulator of Wnt signaling. Proc Natl Acad Sci USA. 2008; 105(40): 15417-22. https://doi.org/10.1073/pnas.0807763105.

53. Shi XE, Li YF, Jia L, Ji HL, Song ZY, Cheng J, et al. MicroRNA-199a-5p affects porcine preadipocyte proliferation and differentiation. Int J Mol Sci. 2014; 15(5): 8526-38. https:// doi.org/10.3390/ijms15058526.

54. Kim JY, Shin KK, Lee AL, et al. MicroRNA-302 induces proliferation and inhibits oxidant-induced cell death in human adipose tissue-derived mesenchymal stem cells. Cell Death Dis. 2014; 5:e1385. https://doi.org/10.1038/cddis.2014.344.

55. Han J, Li L, Wang D, et al. -Hydroxycitric acid reduced fat deposition via regulating lipid metabolismrelated gene expression in broiler chickens. Lipids in health and disease. 2016; 15(1): 37. https://doi.org/10.1186/s12944-016-0208-5.

56. Bae H, Hong KY, Lee Ck, et al. Angiopoietin-2-integrin a5 $\beta 1$ signaling enhances vascular fatty acid transport and prevents ectopic lipid-induced insulin resistance. Nat Commun. 2020; 11: 2980. https://doi.org/10.1038/s41467-020-16795-4.

57. Li Z, Li C, Wu Q. et al. MEDAG enhances breast cancer progression and reduces epirubicin sensitivity through the AKT/AMPK/mTOR pathway. Cell Death Dis. 2021; 12: 97. https:// doi.org/10.1038/s41419-020-03340-w.

58. Bae YJ, Kim SE, Hong SY, et al. Time-course microarray analysis for identifying candidate genes involved in obesity-associated pathological changes in the mouse colon. Genes \& Nutrition. 2016; 
11(1):30-41. https://doi.org/10.1186/s12263-016-0547-x.

59. Patel YM, Lane MD. Role of calpain in adipocyte differentiation. Proceedings of the National Academy of Sciences of the United States of America. 1999; 96(4):1279-1284. https://doi.org /10.1073/pnas.96.4.1279.

60. Stewart A, Guan H, Yang K. BMP-3 promotes mesenchymal stem cell proliferation through the TGFbeta/activin signaling pathway. Journal of cellular physiology. 2010; 223(3):658 \pm 66 . https://doi.org/10.1002/jcp.22064.

61. Qing X, Sen L, Yong W, et al. Fibroblast growth factor 10 (FGF10) promotes the adipogenesis of intramuscular preadipocytes in goat. Mol Biol Rep. 2018; 45(6): 1881-1888. https://doi.org/10.1007/s11033-018-4334-1.

62. Xiong $Y, X u Q$, Lin $S$, Wang $Y$, Lin $Y Q, Z$ Zhu JJ. Knockdown of $L X R a$ inhibits goat intramuscular preadipocyte differentiation. International Journal of Molecular Sciences. 2018; 19(10): 3037. https://doi.org/10.3390/ijms19103037.

63. Shang Z, Guo L, Wang N, Shi H, Wang Y, Li H. Oleate promotes differentiation of chicken primarypreadipocytes in vitro. Bioscience Reports. 2014; 34(1): 51-57. https://doi.org/ 10.1042/ BSR20130120.

64. Andrews S. FastQC A Quality Control tool for High Throughput Sequence Data. Soil.2020. https://www.bioinformatics.babraham.ac.uk/projects/fastqc.

65. Bai B, Wu J, Sheng WT, Zhou B, Zhou LJ, Zhuang W, et al. Comparative Analysis of Anther Transcriptome Profiles of Two Different Rice Male Sterile Lines Genotypes under Cold Stress. International Journal of Molecular Sciences. 2015; 16(5): 11398. https://doi.org/10.3390/ ijms160511398.

66. Kim D, Langmead B, Salzberg S. HISAT: a fast spliced aligner with low memory requirements. Nat Methods. 2015; 12: 357-360. https://doi.org/10.1038/ nmeth.3317.

67. Guttman M, Garber M, Levin JZ, Donaghey J, Robinson J, Adiconis X, et al. Ab initio reconstruction of cell type-specific transcriptomes in mouse reveals the conserved multi-exonic structure of lincRNAs. Nature Biotechnology. 2010; 28(5): 503. https://doi.org/10.1038 /nbt.1633.

68. Trapnell C, Williams BA, Pertea G, Mortazavi A, Kwan G, van Baren MJ, et al. Transcript assembly and quantification by RNA-Seq reveals unannotated transcripts and isoform switching during cell differentiation. Nature Biotechnology. 2010; 28(5): 511-515. https:// doi.org/10.1038/nbt.1621.

69. Kong L, Zhang Y, Ye ZQ, Liu XQ, Zhao SQ, Wei L, et al. CPC: assess the protein-coding potential of transcripts using sequence features and support vector machine. Nucleic Acids Research. 2007; 35 (Web Server issue): W345. https://doi.org/10. 1093/nar/gkm391.

70. Kaplan RS, Roll R. Investor Evaluation of Accounting Information: Some Empirical Evidence. Journal of Business. 1972; 45(2): 225-257. https://doi.org/10.2307/2352032.

71. Finn RD, Coggill P, Eberhardt RY, Eddy SR, Mistry J, Mitchell AL, et al. The Pfam protein families database: towards a more sustainable future. Nucleic Acids Research. 2016; 44(Database issue): D279-D285. https://doi.org/10.1093/nar/gkv1344. 
72. Huang DW,Sherman BT, Lempicki RA. Bioinformatics enrichment tools: paths toward the comprehensive functional analysis of large gene lists. Nucleic Acids Res. 2009; 37(1):1-13. https://doi.org/10.1093/nar/gkn923.

73. Robinson MD, Mccarthy DJ, Smyth GK. edgeR: a Bioconductor package for differential expression analysis of digital gene expression data. Bioinformatics. 2010; 26: 139-140.

74. Xu Q, Lin S, Zhu JJ, Wang Y, Lin YQ. The expression stability analysis of reference in the process of goat intramuscular preadipocytes differentiation in goat. Acta Veterinaria et Zootechnica Sinica. 2018; 49(5): 907-918. https://doi.org/10.11843/j.issn.0366-6964.

75. Livak KJ, Schmittgen TD. Analysis of relative gene expression data using real-time quantitative PCR and the 2(-Delta Delta C(T)) Method. Methods. 2000; 25(4): 402-408.

https://doi.org/10.1006/meth.2001.1262.

\section{Figures}

$\mathbf{A}$

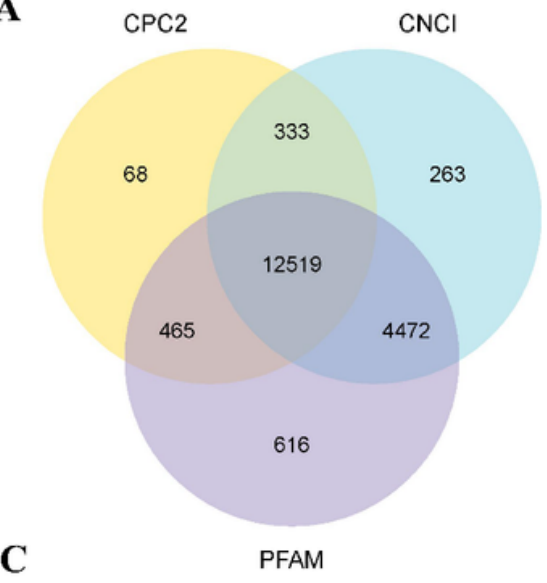

B FPKM density distribution
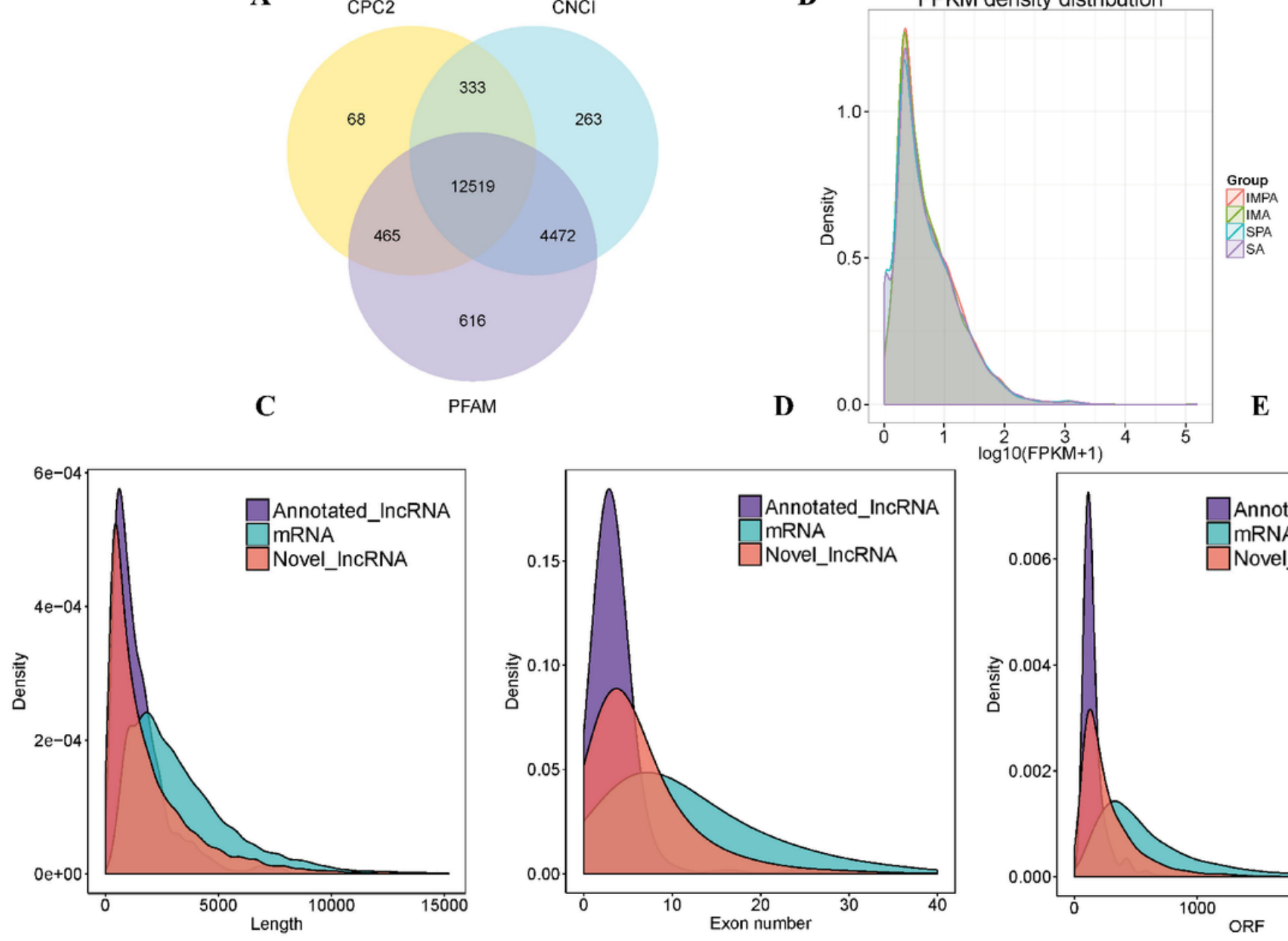

E

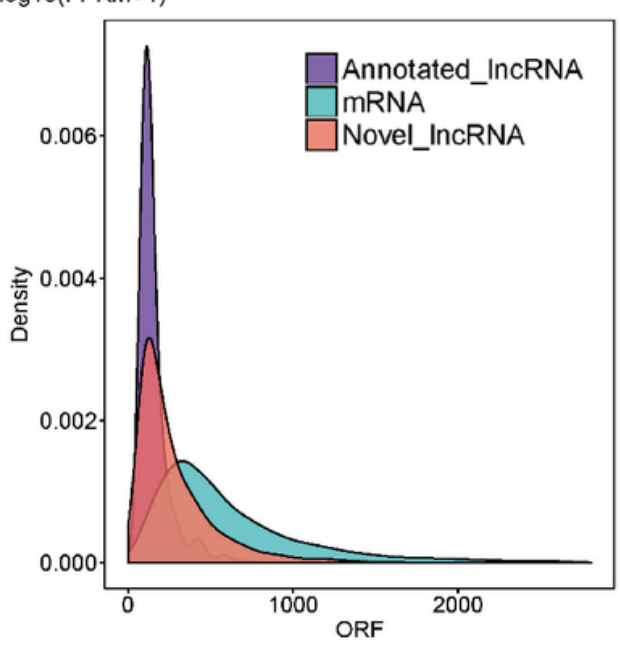

Figure 1 
Identification and characterization of IncRNAs in goat, Capra hircus. (A) Venn diagrams of coding potential analysis by using stringent criteria. Three tools (CPC2, $\mathrm{CNCl}$ and PFAM) were employed to analyze the coding potential of IncRNAs. Those simultaneously shared by three analytical tools were designated as candidate IncRNAs and used in subsequent analysis. (B) Volcanic maps of differentially expressed RNA. The expression levels of mRNAs and IncRNAs were indicated by log10 (FPKM + 1). (C) Length distribution of mRNAs and IncRNAs, unit of the length is bp. (D) Distribution of exon number in the mRNAs and IncRNAs. (E) Open reading frame (ORF) length distribution for mRNAs and IncRNAs.

A

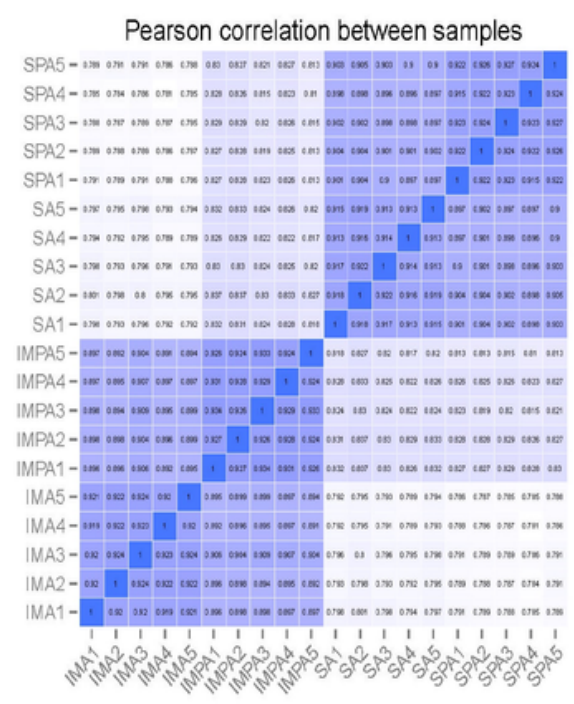

B

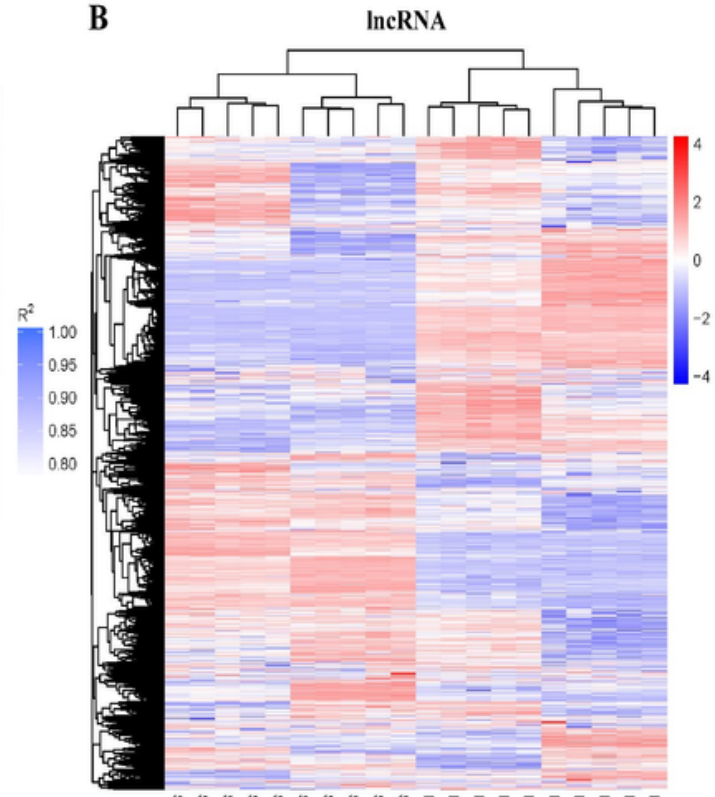

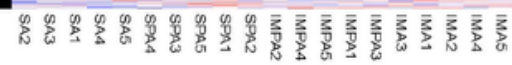

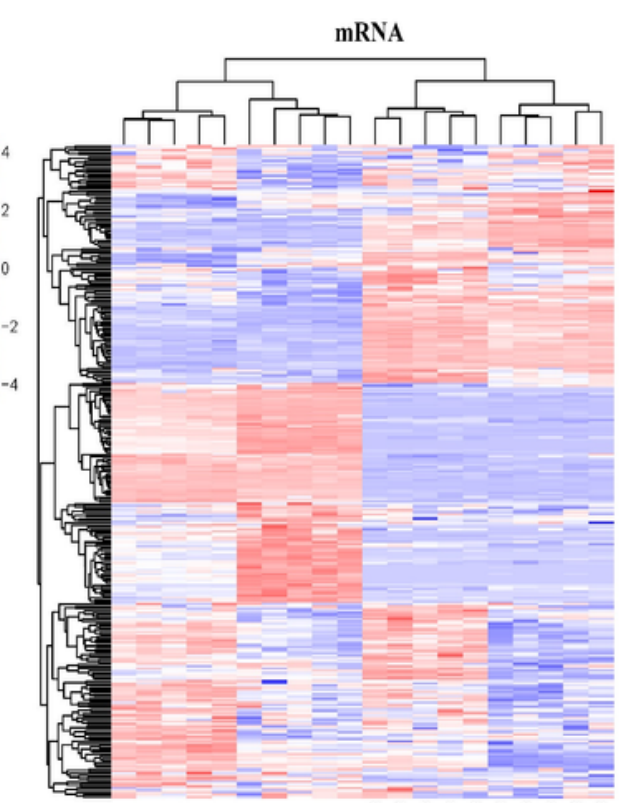

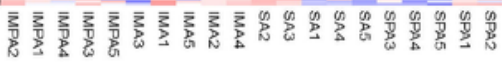

C
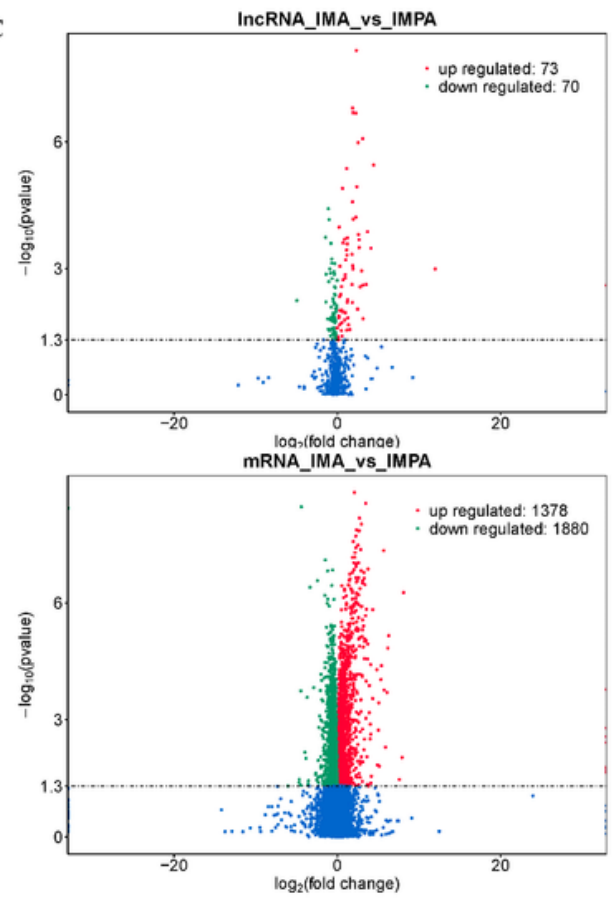
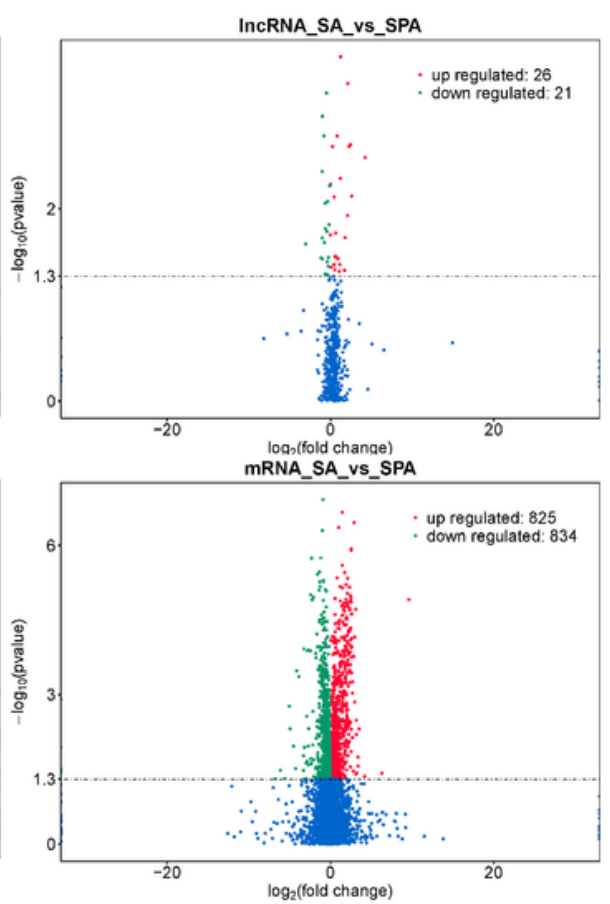


\section{Figure 2}

Differentially expressed coding genes and IncRNAs in goat adipocytes between intramuscular and subcutaneous of differentiation (Fold Change $\geq 2$ and P-adjust value $\leq 0.05$ ). (A) Representative of the degree of similarity between samples. The correlation coefficient is represented by color; deeper color represents a stronger correlation. (B) Clustering analysis of differentially expressed IncRNAs and mRNAs in IMA vs IMPA and SA vs SPA. (C) Volcano plot of differentially expressed IncRNAs and mRNAs in IMA vs IMPA and SA vs SPA. Green and red represent downregulated and upregulated expression, respectively.

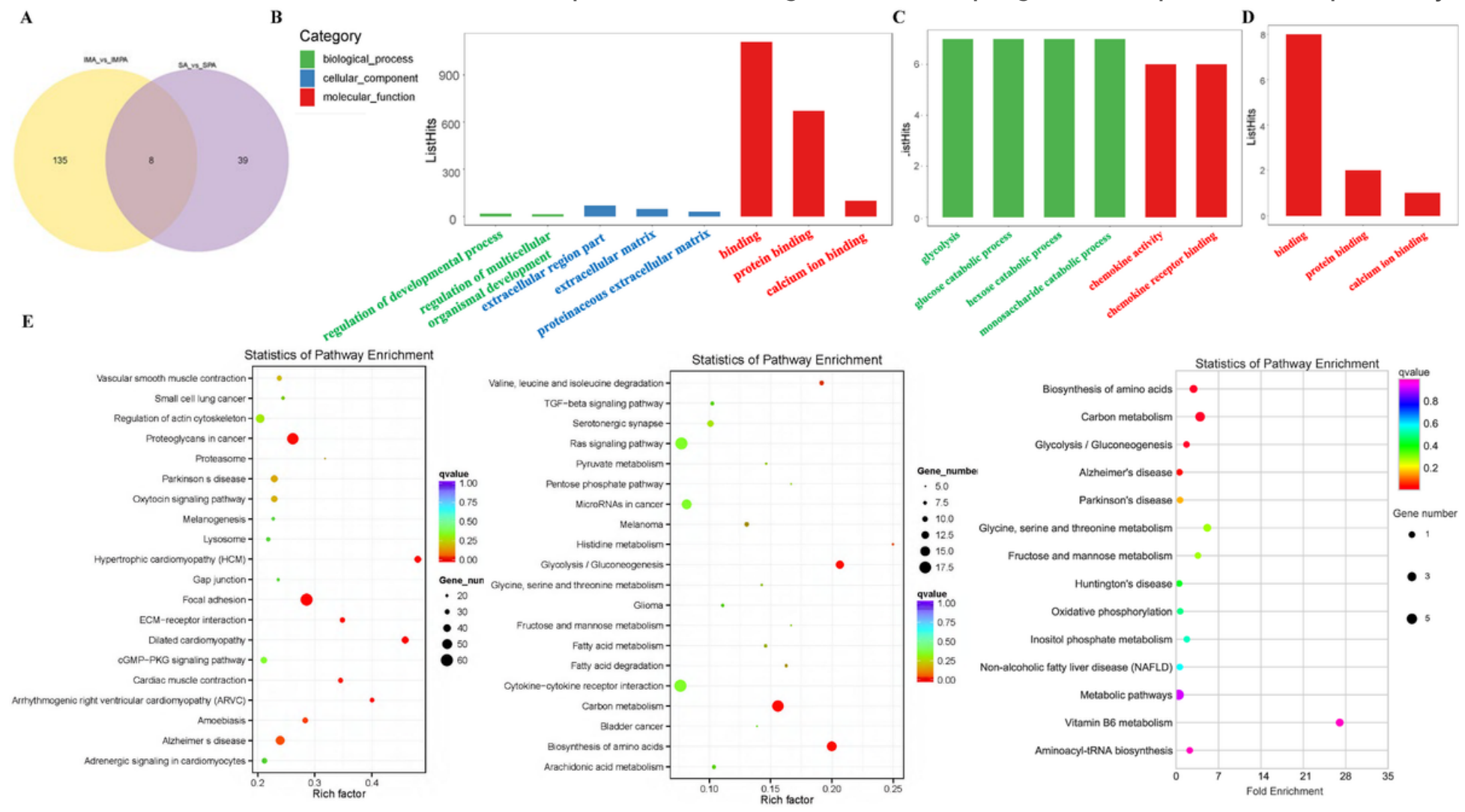

\section{Figure 3}

GO and KEGG enrichment analyses of differentially expressed IncRNAs in goat different adipocytes. (A) Venny maps of differentially expressed IncRNAs during intramuscular and subcutaneous preadipocyte differentiation. (B) Categories of biological processes, cellular components and molecular functions of the target genes of differentially expressed IncRNAs (intramuscular adipocytes). (C) Categories of the biological processes and molecular functions of the target genes of differentially expressed IncRNAs (subcutaneous adipocytes). (D) Categories of molecular functions of the target genes of differentially expressed IncRNAs (both subcutaneous and intramuscular adipocytes). (E) Scatter plot of the top 20 pathways enriched for differentially expressed IncRNAs in intramuscular adipocytes before and after differentiation. (F) Scatter plot of the top 20 pathways enriched for differentially expressed IncRNAs in subcutaneous adipocytes before and after differentiation. (G) Scatter plot of the top 15 pathways enriched for differentially expressed IncRNAs in both intramuscular and subcutaneous adipocytes before 
and after differentiation. The abscissa represents the richness factor, and the ordinate represents the enriched pathway terms. The Q-value represents the corrected $\mathrm{P}$ value.

A

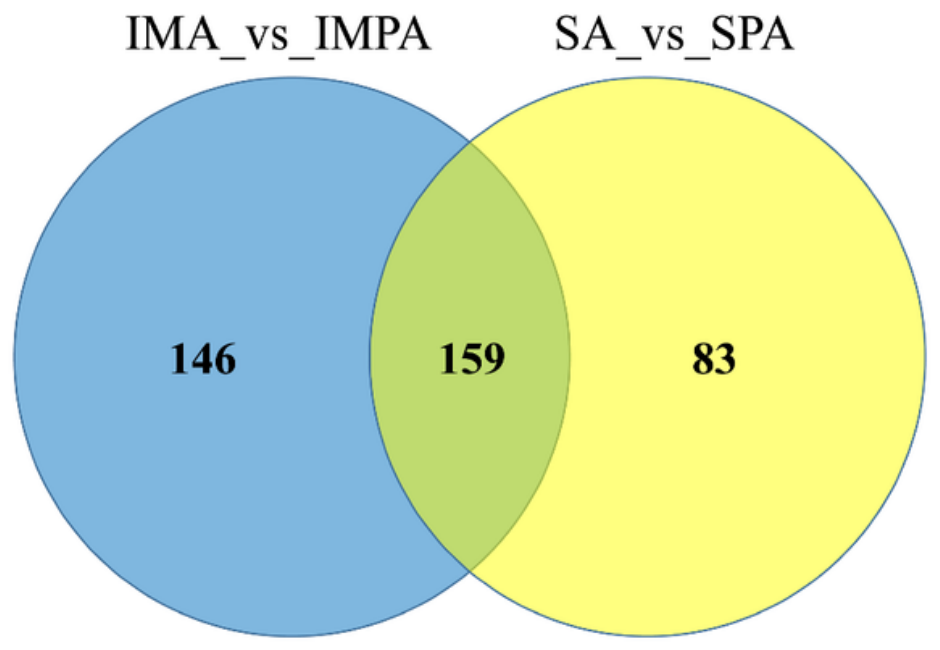

B

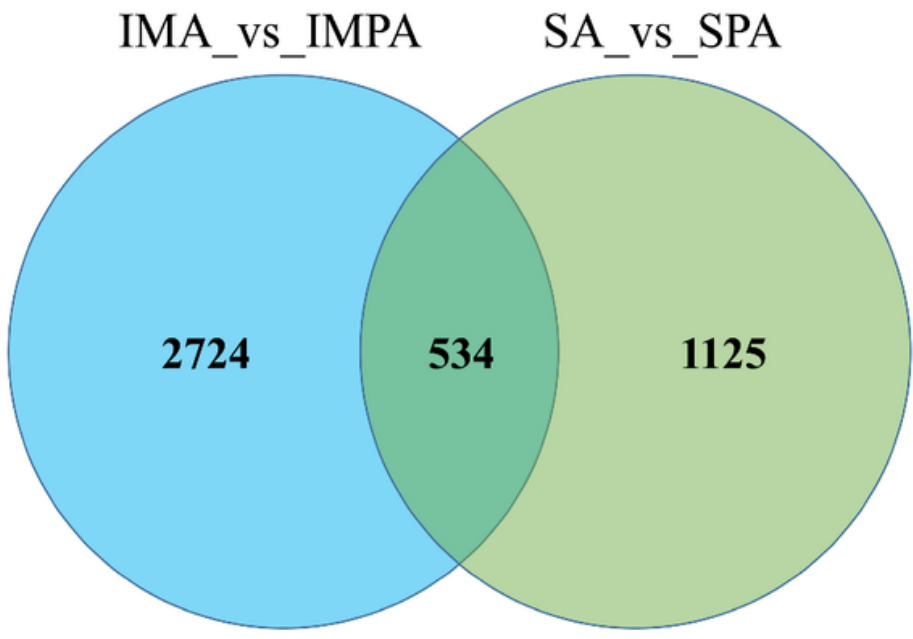

\section{Figure 4}

Venny maps of differentially expressed RNAs. Venny maps showing specific miRNAs (A) and mRNAs (B), respectively, in intramuscular adipocytes or subcutaneous adipocytes.
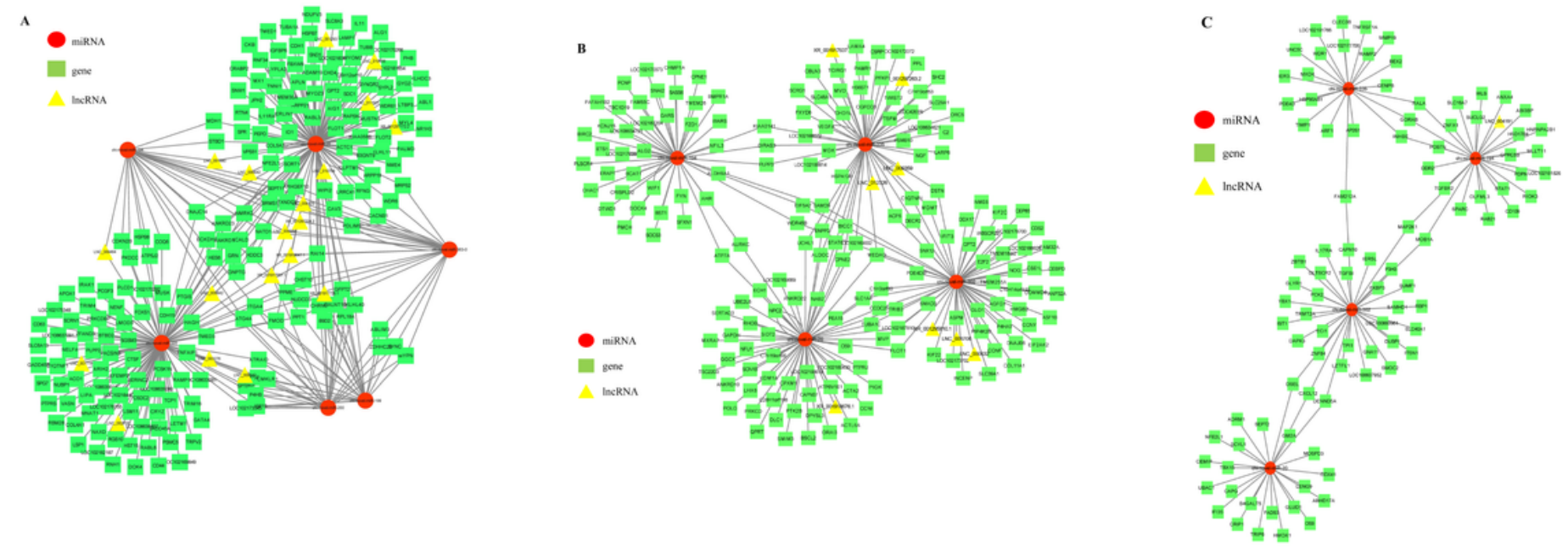

\section{Figure 5}

IncRNA-miRNA-mRNA network. (A) Regulatory network of intramuscular adipocytes before and after differentiation. Nodes with Closeness Centrality $>6.4815 \mathrm{E}-4$ are discarded. Closeness Centrality is the reciprocal of the sum of the shortest paths from a point to all other points, and the larger it is, the shorter the path from that point to all other points and the closer it is to the center in space. (B) Regulatory network of subcutaneous adipocytes before and after differentiation. (C) There is a common network of intramuscular and subcutaneous adipocytes before and after differentiation. 


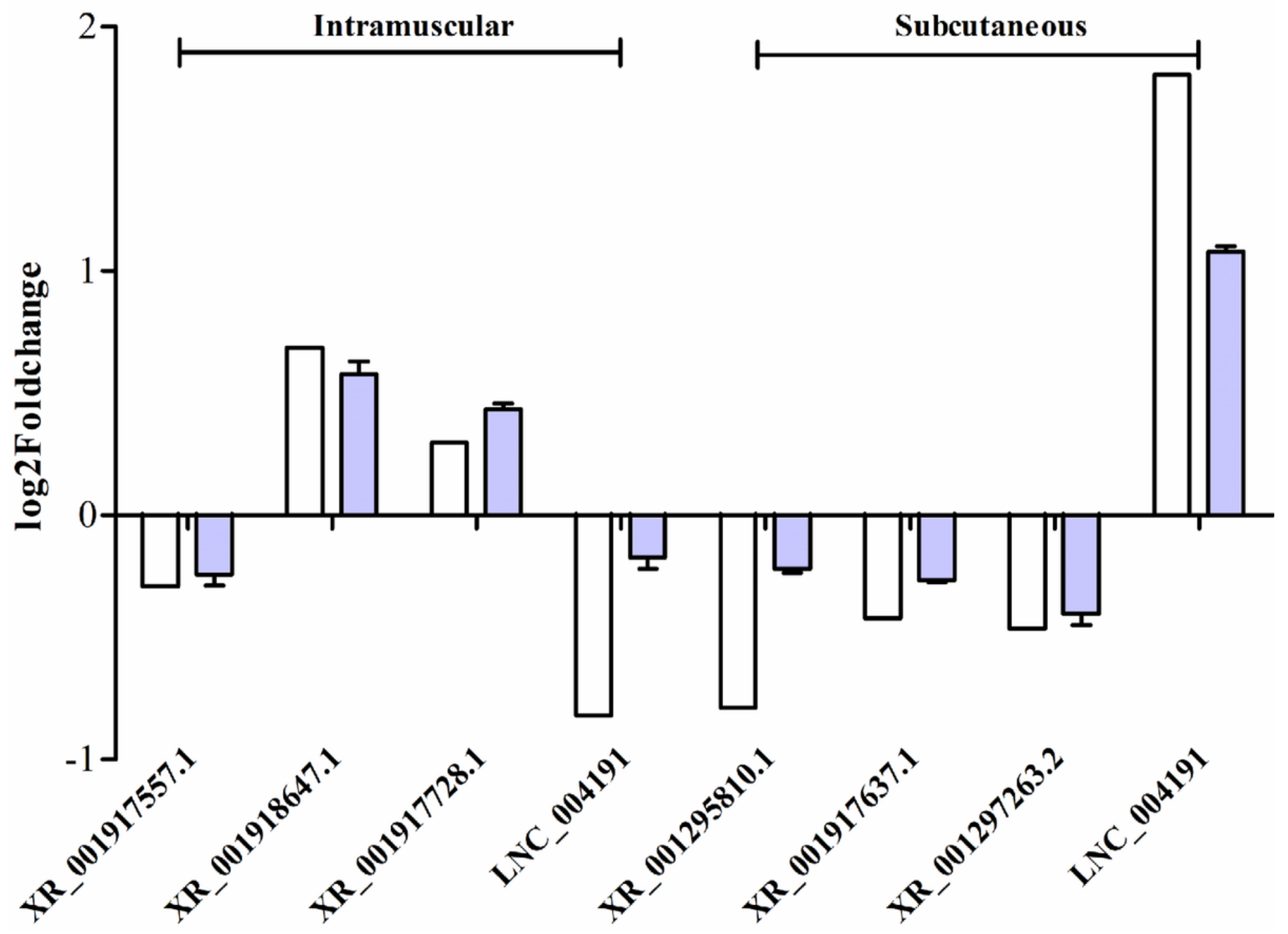

Figure 6

Validation of IncRNAs in intramuscular and subcutaneous adipocytes using RT-qPCR technique. Data were analyzed by the 2- $\Delta \Delta \mathrm{Ct}$ method where the UXT was used as a reference gene. Each column represents the mean $\pm S E$. White bars represent read from RNA-Seq, and blue bars represent the results from qRT-PCR analysis.

\section{Supplementary Files}

This is a list of supplementary files associated with this preprint. Click to download.

- Supplement1IncRNAIMAvsIMPA.DE.xls

- Supplement2IncRNASAvsSPA.DE.xls

- Supplement3miRNAIMAvsIMPA.DE.xls

- Supplement4miRNASAvsSPA.DE.xls 
- Supplement5mRNAIMAvsIMPA.DE.xls

- Supplement6mRNASAvsSPA.DE.xls

- Supplement7DEIncRNAmRNA.xls

- Supplement8DEmiRNAlncRNA.xls

- Supplement9DEmiRNAmRNA.xls 